\title{
The Positive Impact of SFE Learning Model Assisted with Mind mapping Media Toward Students' Knowledge Competence in Science
}

\author{
I Md Yuda Bagaskara \\ Program Studi Pendidikan Guru Sekolah Dasar, FIP, Universitas Pendidikan Ganesha, Singaraja, Indonesia \\ Email: imadeyudabagaskara250597@gmail.com \\ Dewa Nym. Sudana \\ Program Studi Pendidikan Guru Sekolah Dasar, FIP, Universitas Pendidikan Ganesha, Singaraja, Indonesia \\ Email: dewanyoman.sudana@undiksha.ac.id \\ Kd Yudiana \\ Program Studi Pendidikan Guru Sekolah Dasar, FIP, Universitas Pendidikan Ganesha, Singaraja, Indonesia \\ Email:kadek.yudiana@undiksha.ac.id
}

\section{A R T IC L E I N F O \\ Article history: \\ 1 Mei 2020 Received in \\ revised form \\ 11 Juni 2020 \\ Accepted 10 Juli 2020 \\ Available online 25 Agustus \\ 2020 \\ Kata Kunci: \\ SFE, mind mapping, \\ kompetensi pengetahuan. \\ Keywords: \\ SFE learning model, mind \\ mapping, science \\ knowledge competencies.}

\begin{abstract}
A B S T R A K
Permasalahan rendahnya kompetensi pengetahuan IPA pada siswa kelas V SD di Gugus VIII Kecamatan Kintamani menjadi masalah utama dilakukannya penelitian ini. Rendahnya kompetensi pengetahuan IPA siswa terjadi karena pembelajaran masih bersifat teacher center dan minimnya penggunaan media pembelajaran. Oleh karena itu penelitian ini dilakukan dengan tujuan untuk menganalisis pengaruh model pembelajaran student facilitator and explaining (SFE) berbantuan media Mind mapping terhadap kompetensi pengetahuan IPA pada siswa kelas V SD. Jenis penelitian ini adalah eksperimen semu dengan desain Non-Equivalen Post-test Only Control Group Design. Populasi dalam penelitian ini adalah seluruh kelas V SD Gugus VIII Kecataman Kintamani yang berjumlah 111 siswa. Sampel dalam penelitian ini diambil dengan teknik random samping, didapatkan kelas V SD Negeri Abangsongan sebagai kelompok eksperimen yang berjumlah 26 siswa dan kelas V SD Negeri Suter sebagai kelompok kontrol yang berjumlah 25 siswa. Data dikumpulkan menggunakan metode tes kompetensi pengetahuan IPA dalam bentuk tes objektif pilihan ganda. Data kompetensi pengetahuan IPA dianalisis dengan menggunakan teknik analisis statistik deskriptif dan statistik inferensial dengan taraf signifikansi 5\%. Dari hasil analisis data, diperoleh thitung 5,76 $>t_{\text {tabel }} 2,00$. Sehingga $\mathrm{H}_{0}$ ditolak. Itu berarti bahwa terdapat terdapat pengaruh yang
\end{abstract} signifikan model pembelajaran $S F E$ berbantuan media Mind mapping terhadap kompetensi pengetahuan IPA pada siswa kelas V SD di Gugus VIII Kecamatan Kintamani. Untuk penelitian yang memiliki kesamaan variabel, hasil penelitian ini dapat dipergunakan sebagai kajian penelitian relevan.

\section{A B S T R A C T}

The problem in the low science knowledge competence in fifth-grade elementary school students at Gugus VIII, Kecamatan Kintamani, is the main research problem. The students' low science knowledge competence occurs because learning is still a teacher centre and the minimal use of learning media. Therefore, this study was conducted to analyse the effect of the student facilitator and explain (SFE) learning model assisted by Mind mapping media on science knowledge competence at fifthgrade elementary school students. This type research is a quasi-experimental design with Non-Equivalent Post-test Only Control Group Design. The population in this study were all fifth grade SD Gugus VIII Kecamatan Kintamani, consisted of 111 students. The sample in this study was taken by side random technique, it was found that the fifth grade SD Negeri Abangsongan as an experimental group which consisted of 26 students and the fifth grade of SD Negeri Suter as a control group which consisted of 25 students. Data collected used the science knowledge competency test method in multiple-choice objective tests. Science knowledge competency data analysed using descriptive statistical analysis techniques and inferential statistics with 5\%. Significance level. From the data analysis results, tcount 5.76> ttable 2.00. So that H0 rejected. It means that there is a significant effect of the SFE learning model assisted by Mind mapping media on the science knowledge competence atfifth-grade elementary school students in Gugus VIII, Kecamatan Kintamani. For research that has the same variables, the results can be used as a study of relevant research.

\section{Introduction}

Curriculum development is very important to do along with the times. Changing the curriculum by the government is to improve the education quality so that it is relevant to the era. The current curriculum applied in 
Indonesia is the 2013 curriculum. In general, the 2013 curriculum has four core competencies, spiritual attitudes, social attitudes, knowledge, and skills. The 2013 curriculum is applied to all education levels, which is for elementary school level. The 2013 Curriculum application in elementary schools, learning materials are integrated into a theme called integrated thematic (Masnun, 2016; Mulyadin, 2016). This theme is a combination of several subject matter that is relevant to elementary school competence. One of the contents that integrated into a theme is science subjects. Science is an objective and rational science that study about universe with natural phenomena and everything in it (Samatowa, 2010). The purpose of science subject is to develop students' potential related to solving problems, investigating the surrounding environment, and being able to increase awareness in preserving the natural environment. Natural science content is very important for elementary students, because students will be taught to know the environment and be sensitive to various problems that arise in the natural environment (Putra, 2017; Sophuan, 2018). This will be very useful for everyday life.

However, in reality when interviews were conducted on October 18-21 2019 with several fifth-grade elementary school teachers in gugus VIII, kecamatan Kintamani, there are several problems, students are less enthusiastic in participating in science learning. This is due to the lack of learning media in the classroom. The teacher stated that the students' competence in science was still low. After the interview conducted, it was continued by observing the learning process in the fifth grade at SD gugus VIII, kecamatan Kintamani on October 18-21 2019, several problems were found. First, learning is still in the form of a teacher centre in which teachers use more lecturing method and give fewer assignments or questions and answers when the learning takes place. Meanwhile, student involvement in exploring their ability to find the concept of subject matter is still very minimal and they listen more to the material presented by the teacher. Lack of teacher understanding in innovative learning models learning is dominated by the lecturing method. Students feel bored, so they carry out other activities when learning takes place such as joking with classmates, going in and out for various reasons, daydreaming, and not a few students are sleepy in class because they only receive information from the teacher. It makes students not focus on learning so that understanding material possessed by students is not optimal. Second, the use of media is still minimal. The teacher should use learning media when presenting material. Instructional media will be very helpful in delivering material. It can attract students' attention. The use of media will help teachers in presenting scientific material that has a broad material coverage. If teaching with a wide range material and in its presentation without learning media, students will difficult in understanding the learning material. Learning will be boring and less meaningful for students.

Interviews and observations results have been carried out, five grade elementary students' UTS scores was carried out in gugus VIII, kecamatan Kintamani for the 2019/2020 academic year which is presented in Table 1.

Table 1. Minimum completeness criteria and the average score of mid-semester tests

\begin{tabular}{|c|c|c|c|c|c|c|}
\hline \multirow[b]{2}{*}{ No } & \multirow[b]{2}{*}{ School } & \multirow[b]{2}{*}{$\begin{array}{c}\text { Total } \\
\text { Students }\end{array}$} & \multicolumn{2}{|c|}{ Total Students } & \multirow[b]{2}{*}{ KKM } & \multirow[b]{2}{*}{ Average } \\
\hline & & & $\begin{array}{c}\text { Memenuhi } \\
\text { KKM }\end{array}$ & $\begin{array}{c}\text { Tidak } \\
\text { Memenuhi } \\
\text { KKM }\end{array}$ & & \\
\hline 1 & SDN 1 Abang Batudinding & 35 & 11 & 24 & 68 & 63,68 \\
\hline 2 & SDN 2 Buahan & 14 & 3 & 11 & 70 & 63,35 \\
\hline 3 & SDN 2 Terunyan & 11 & 4 & 7 & 69 & 63,18 \\
\hline 4 & SDN Abangsongan & 26 & 8 & 18 & 69 & 59,84 \\
\hline 5 & SDN Suter & 25 & 7 & 18 & 68 & 61,44 \\
\hline & Total & 111 & 33 & 78 & & \\
\hline
\end{tabular}

Based on Table 1, out of 111 students, 78 students had not fulfilled the KKM. When viewed from the average UTS score from each school, the range 59.84-63.68 included in the low category, based on the 5 scale benchmark reference (PAP) assessment (Agung, 2016). Based on these data, it showed that students' competence in scientific knowledge is still low. The situation as described, if left unchecked, will certainly affect the students' science knowledge competence. This problem needs a solution so the learning carried out can provide optimal results and be able to increase students' competence in science knowledge. It is necessary to apply a learning model that can provide opportunities for students to build knowledge based on real student experiences and motivate students to actively participate in learning. One solution that can be used is an innovative learning model. It can be seen that the teacher's understanding in innovative learning models is still not optimal. Many innovative learning models can be chosen as an effort to overcome the problem in science knowledge low competency. The learning model used must be adapted to the students' characteristics.

The SFE learning model is a model that can be used to overcome these problems. The SFE learning model is a learning that focuses on student activities to learn to convey material, opinions, and ideas to other 
fellow students (Huda, 2013). The SFE learning model is a cooperative learning model which is a learning model that adopts constructivism. The SFE learning model is learning that emphasizes a special structure designed to influence the students' interaction patterns has a goal to understand the material (Shoimin, 2014). This model trains students to be able to present their ideas or ideas to their friends. The SFE model in classroom learning is more student-centred. This learning model following the science content characteristics. This learning model provides opportunities for students to play an active role in learning such as seeking information, processing information, and concluding it in the form of group discussions to be explained to other fellow students (Fauzi et al., 2016; Huda, 2013). Then through the process of seeking information and processing information, students will indirectly gain knowledge related to natural phenomena. The advantages and disadvantages of the SFE model are (1) The material presented is clearer and more concrete (2) It can increase student absorption because learning is done by demonstration (3) Train students to act as teachers (4) Spur student motivation to be the best in explaining the teaching material (5) Determining the student's ability to conclude ideas or ideas. While the shortcomings of this model are (1) Students who are shy do not want to demonstrate what the teacher instructs him or many students are less active (2) Not all students have the same opportunity to do it or explain back to their friends because of limited learning time (3) There is the same opinion so that only some are skilled (4) It is not easy for students to make concept maps or explain teaching materials briefly (Fauzi et al., 2016).

The SFE learning model can stimulate students to actively participate in learning, train students to interact with other students, share information about assignments or questions given by the teacher, train students to speak to express opinions, teach students to be disciplined, teach students to respect each other's opinions, and teach students to practice mastering learning material. This learning model will increase the student's learning experience so that it makes students happy, comfortable, enthusiastic, active, and creative which can create meaningful learning. The SFE learning model is strengthened by the relevant research studies conducted (Lestari, 2014). Based on the research conducted, it was found that the SFE learning model had a positive influence on students' science learning outcomes.

Learning model is more effective when assisted by a media. The existence of learning media can make it easier for a teacher to present material. The media used in science learning is Mind mapping media which is packaged by including ideas or main material related to science material. Mind mapping model is easy to use and effective. It can make students more active in learning both in issuing information, ideas and new ideas, especially it can make it easier for students to understand teaching material that has been given (Hendrawan, 2017). Mind mapping is one way that can help students organize the information obtained in the form of a chart or concept map (Fauzi et al., 2016). Mind mapping is a technique of summarizing the material that needs to be studied, and projecting the problems faced in the form of maps or graphic techniques so that it is easier to understand (Ratnani, 2019). Learning with Mind mapping media aims to create visually and graphically patterned material which in turn can help record, strengthen and recall the information that has been learned, and the use of Mind mapping media in learning can maximize student understanding, because the material presentation through Mind Mapping is packaged in a structured manner by presenting ideas or an outline of the material itself (Ratnani, 2019). The use of Mind mapping media will be able to attract students' attention in taking part in learning because Mind mapping media is packaged in an attractive appearance. Mind mapping can help students in (1) be more creative, (2) save time, (3) solve problems, (4) concentrate, (5) remember, (6) learn faster, more efficiently, and easier (Fauzi et al., 2016). Thus, it is hoped that science learning will be more cared by students and teachers to have innovations in presenting material. The science learning objectives can be achieved optimally.

Several studies that found that the SFE model affected the science competence, research conducted by (Ratnani, 2019) entitled the effect of the SFAE learning model providing Mind mapping on student Civics learning outcomes. This study states that there is an effect of the Student Facilitator And Explaining (SFAE) learning model with Mind Mapping that affects the learning outcomes at fifth-grade elementary school students. This can be seen from the average student learning outcomes using the SFE model higher than the average student learning outcomes without using the group investigation model. This research is related to the research that will be carried out, the SFE model and mind mapping media. The difference between this research and the research that will be carried out is that this research examines the learning outcomes of Civics while the research that will be carried out examines the science knowledge competence.

This research purpose was to analyse the effect of the SFE learning model assisted by Mind mapping media on the science knowledge competence at fifth-grade elementary students in gugus VIII, kecamatan Kintamani, Academic Year 2019/2020. The steps for the SFE learning model are: (1) the teacher delivers the material and competencies to be achieved, (2) the teacher presents an outline of the learning material, (3) The teacher provides opportunities for students to explain to other students, for example through concept maps and others, (4) the teacher provides the opportunity for students to explain the material in front of the class, for example through previously made charts, (5) the teacher summarizes the students' opinions, (6) the teacher explains the material presented at that time, (7) ) closing (Fauzi et al., 2016). 


\section{Method}

This research is classified as a quasi-experiment. The design used in this study was the non-equivalent posttest-only control group design. In this design, two groups are the sample in this study, namely the experimental group and the control group. The experimental group was given treatment or treatment in the form of SFE learning model assisted by Mind mapping (X) media. While the control group did not get treatment or treatment with learning that did not use the SFE learning model assisted by Mind mapping (-) media. At the end of the meeting, the experimental group and the control group were both given a post-test $(\mathrm{O} 1$ and $\mathrm{O} 2)$ in knowledge competency test, a written test.

The population in this study were all fifth-grade elementary school students in gugus VIII, kecamatan Kintamani. The sample determination using a simple random sampling technique. The research sample was taken as many as 51 students from 2 (two) elementary schools, SD Negeri Abangsongan as the experimental group and SD Negeri Suter as the control group.

To find out whether the science knowledge competence in fifth-grade students of each elementary school is equivalent or not, then the equivalence test is first carried out using the one-way analysis of variance formula (ANAVA A) at the 5\% significance level, it is obtained fcount $=0.51$ smaller than ftabe $1=3.93$, so $\mathrm{H} 0$ is accepted. Thus, fifth-grade elementary school ability in science content in gugus VIII, kecamatan Kintamani for the 2019/2020 academic year declared equal.

The data collection technique in this study was test-giving. The test technique is used for the students, science knowledge competence. The test used in this study is a multiple-choice objective test. The instrument validity used the content validity test with 2 (two) experts. After conducting the test trials, the results obtained were analyzed using the item validity test, test reliability test, item difficulty index test, and difference power index test. The following is the grid for the objective test instruments in Table 2.

Table 2. Objective test instruments

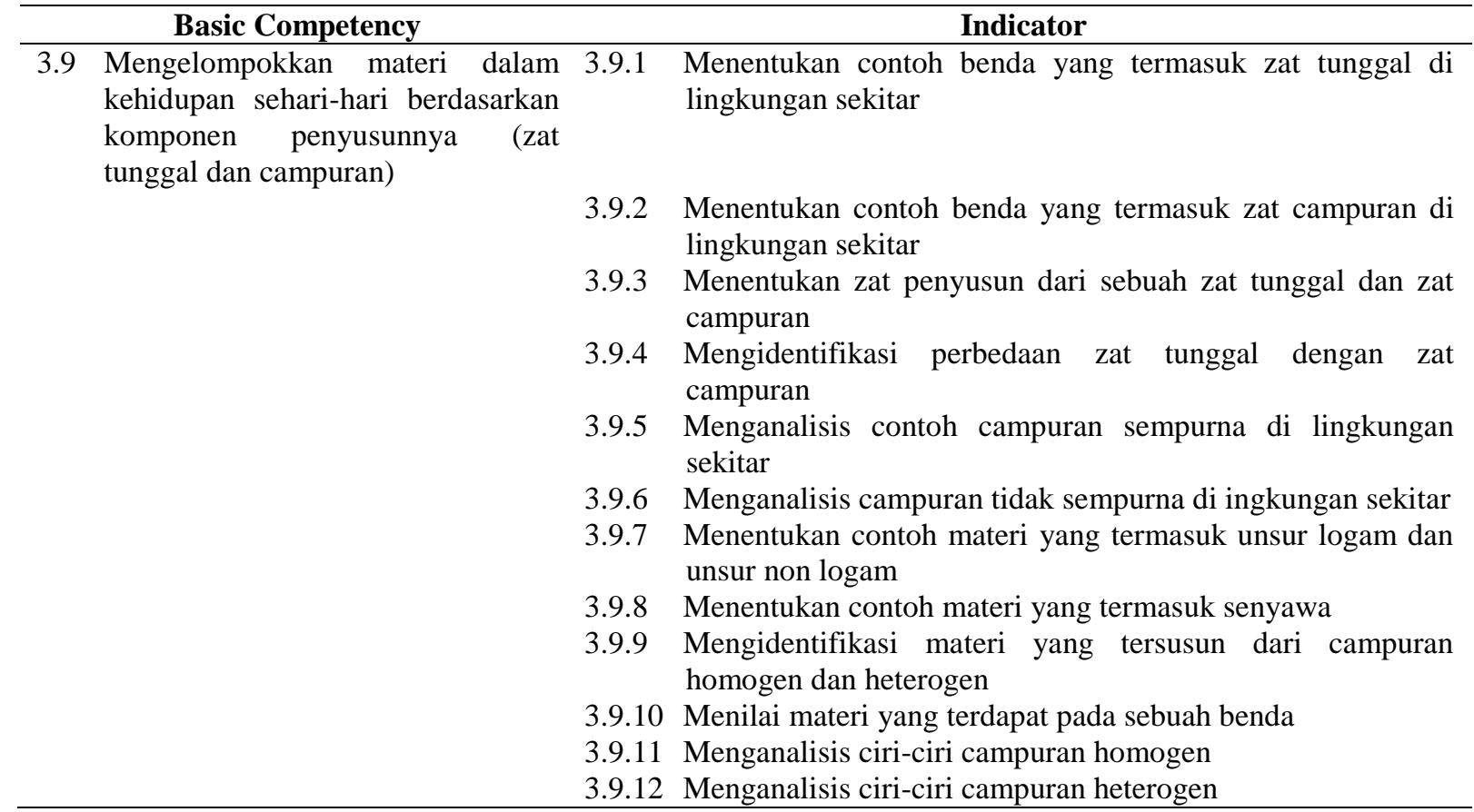

The data analysis method in this study using descriptive statistical analysis methods and inferential statistics. Descriptive statistical analysis was used to describe the data in the form of high and low quality research variables, the learning model and the elementary students' science knowledge competence. Descriptive analysis displays the mode, median, mean, standard deviation, variance, maximum value, minimum value, frequency distribution table, and polygon graph for each research variable. Inferential statistical analysis carried out two tests, namely the prerequisite test and hypothesis testing. The prerequisite test includes the data distribution normality test and the variance homogeneity test. To test the research hypothesis used t-test analysis with the polled variance formula. Polled variance was used in testing the hypothesis because the sample members in the experimental group and control group was not the same, and the variance was homogeneous. 


\section{Result and Discussion}

The students' science knowledge competency data were obtained from the post-test results given to the two research samples. The post-test result for fifth-grade students at SD Negeri Abangsongan and SD Negeri Suter are presented in Table 3.

Table 3. Post-Test Results for Experiment Group and Control Group

\begin{tabular}{cccc}
\hline \multicolumn{2}{c}{ Experiment Group } & \multicolumn{2}{c}{ Control Group } \\
\hline Mode & 24,88 & Mode & 16,12 \\
Median & 24,4 & Median & 16,66 \\
Mean & 23,96 & Mean & 17,08 \\
Deviation standard & 4,24 & Deviation standard & 4,32 \\
Variants & 17,958 & Varian & 18,66 \\
\hline
\end{tabular}

Based on Table 2, it can be described the science knowledge competency post-test results of the experimental group with a mode score was 24.88 , a median score was 24.4 , a mean score was 23.96 , a standard deviation score was 4.24, and a variant score was 17.958. Meanwhile, the post-test data on the science knowledge competency of the control group with a mode score was 16.12 , a median score was 16.66 , a mean score was 17.08 , a standard deviation score was 4.32 , and a variance score was 18.66 .

To determine the science knowledge competency distribution data in the experimental group and the control group, the mode, median, and mean values were compared. The experimental group distribution scores is a negative squint curve when viewed from the mode (Mo), median (Md), and mean (M) scores. Because the comparison of the mode, median, and mean values is Mo> Md>M (24.88>24.4> 23.96). This shows that the scores' distribution in the experimental group tends to be high. Meanwhile, the control group score distribution is a positive squint curve when viewed from the mode (Mo), median (Md), and mean (M) scores. Because the mode, median, and mean score comparison is $\mathrm{Mo}<\mathrm{Md}<\mathrm{M}(16.12>16.66>17.08)$. It showed that the score distribution in the experimental group tends to be low.

The average students' science knowledge competency score in the experimental group was 23.96. Based on the conversion results, it was concluded that the average science knowledge competency score in the experimental group students was in the very high category. While students' science knowledge competency average score in the control group was 17.08. Based on the conversion results, it was concluded that the average science knowledge competence in the control group was in the medium category.

The normality test of the data distribution was carried out to prove that the research data were distributed normally. The data distribution normality test was carried out on the post-test data in experimental group and the control group. The normality test uses the Chi-Square formula $(X 2)$ with the criteria for testing normally distributed data if $X 2$ count $<2$ table, at a significant level $5 \%$ degrees of freedom dk (number of classes intervalparameter-1).

Based on the data analysis that has been carried out, the normality test result of the distribution of the post-test results in experimental group and the control group can be presented in Table 4.

Table 4. Normality Test Results

\begin{tabular}{cccc}
\hline Data & $\mathbf{X}^{\mathbf{2}}$ & $\mathbf{X}^{\mathbf{2}}$ tabel with 5\% significance level & Status \\
\hline Post-test Experiment & 3,828 & 7,815 & Normal \\
Post-test Control & 3,070 & 7,815 & Normal \\
\hline
\end{tabular}

Based on Table 3, the results of calculations in the experimental group obtained score $X 2$ of 3,828 . The score of $X 2$ count is smaller than 2 table $(3,828<7,815)$ so that the data is normally distributed. Meanwhile, the control group obtained a score was 3,070 . The $X 2$ count is smaller than $X 2$ table $(3.070<7,815)$ so that the data is normally distributed.

The variance homogeneity test was carried out on the pairs between the experimental group and the control group. The homogeneity of the data was analyzed using the F-Test formula by comparing the variance between the experimental and control groups. The homogeneity test result presented in table 5. 
Table 5. the results of variance homogeneity test

\begin{tabular}{lccc}
\hline Data Source & $\mathbf{F}_{\text {hitung }}$ & $\mathbf{F}_{\text {tabel }}$ with 5\% significant level & Status \\
\hline Post-test experiment and control group & 1,04 & 4,04 & Homogen \\
\hline
\end{tabular}

Based on Table 4, it is found that Fcount (1.04) < Ftable (4.04), so it can be concluded that the variant of the knowledge competency data of the experimental group and the control group is homogeneous, and based on the normality test of data distribution and homogeneity of variance, the results show that the competency data of science knowledge students in the experimental group and the control group were normally distributed and homogeneous.

Hypothesis testing used the pollen variance t-test formula. Based on the calculation results, it was found that tcount $=5.76$. While $\mathrm{t}$ table with $5 \%$ significance level with $\mathrm{db}=\mathrm{n} 1+\mathrm{n} 2-2=26+25-2=49$, the value of $\mathrm{t}$ table is 2.00 . This means that tcount $>$ ttable (5.76>2.00), so that H0 is rejected and H1 is accepted. This means that there is an influence in Mind mapping-assisted SFE learning model on the competence of science knowledge. The results of the research carried out were that there was an effect of the SFE learning model assisted by Mind mapping media on fifth-grade students at SD Gugus VIII kecamatan Kintamani Academic Year 2019/2020. This effect can be seen from the difference in the average science knowledge competency score of the experimental group and the control group, where the average science knowledge competency score of the experimental group is higher than the average science knowledge competency score of the control group.

There is a difference in science knowledge competence between students who are taught with the mindmapping-assisted SFE learning model and students who are not taught using the mind-mapping-assisted SFE learning model due to differences in learning steps. The use of mind mapping-assisted SFE learning models can make students better understand learning materials optimally. Because the SFE learning model in its learning steps emphasizes student activities to convey material and opinions to colleagues or other students. Students take turns conveying ideas or opinions in front of the class. Before submitting ideas or opinions, students must first prepare themselves by studying teaching materials and conducting group discussions. When delivering material or opinions in front of the class, it is seen that students become more confident in expressing opinions and fluently in conveying opinions or teaching materials, so that students' teaching material understanding is more optimal. The advantages of the SFE learning model make students learn to get ideas out of their minds so that they can better understand the material being studied (Berlin \& Kurniasih, 2015). The SFE learning model provides students the opportunity to convey ideas or opinions about the material being studied, this is supported by research (Shoimin, 2014). So that it has an impact on students' material understanding.

SFE learning model assisted by mind mapping media can make students enthusiastic and more active in participating in learning. The SFE learning model makes classroom learning more active by highlighting the strengths that students have in learning (Huda, 2013). When learning took place, it was seen that students were more enthusiastic in digging up information or material with their group friends and with teacher guidance. The students' activeness is seen when actively interacting with group friends and with the teacher to ask questions and exchange information about the material that students have learned which will then be delivered in front of the class independently. The Student Facilitator and Explaining (SFE) learning model focuses on the process that requires students to become facilitators for their friends, and this process can make students more active when participating in learning activities (Susanto et al., 2014).

The steps of the SFE learning model can also be taken through several stages, namely: (1) the teacher delivers the material and competencies to be achieved, (2) the teacher presents an outline learning material, (3) The teacher provides opportunities for students to explain to students others, for example through concept maps and others, (4) the teacher provides the opportunity for students to explain the material in front of the class, for example through previously made charts, (5) the teacher summarizes the students' opinions, (6) the teacher explains the material presented when that, (7) closing (Fauzi et al., 2016; Sujuni et al., 2014). Through the SFE learning model with these steps, it will make students more active and students will better understand the material presented, so that it will affect knowledge competencies, this is supported by research results (Lestari, 2014) which states that the model SFE learning affects student learning outcomes.

This study result are supported by research results, first by (Mudarini, 2017) showing that the cardassisted SFE learning model has a significant effect on student science learning outcomes, secondly, the research results (Wiratningsih, 2014) show that the media-assisted SFE learning model Concept maps have a significant influence on student PPKn learning outcomes, the three research results (Widyawati, 2016) show that the SFE learning model can activate students in learning so that students become enthusiastic when participating in learning which will have an impact on students' learning outcome understanding in terms of linguistic intelligence. Thus, from some of the relevant studies, no one has supported mind mapping media.

Mind mapping media is new media and has never been encountered by students in learning. Because previously the teacher had never used this media when teaching in class. Mind mapping media can make it easier 
for teachers to deliver learning material, it is hoped that using mind mapping media can train students' right brains to process information, to obtain changes in learning outcomes according to the goals to be achieved (Pujiastuti, 2017). Mind mapping media can make students look very interested in listening to the material presented by the teacher. The use of media when delivering material also provides new experiences for students and makes it easier for students to understand the material because the presentation through mind mapping is structured by presenting ideas or an outline of the learning material so that it makes it easier for students to understand the material. Mind mapping media can make it easier for students to master the concepts of teaching materials that have been given (Hendawati et al., 2018; Hendrawan, 2017).

\section{Conclusion}

Based on the explanation that has been conveyed, it can be concluded that there is a significant effect of the Mind mapping-assisted SFE learning model on science competence in fifth-grade students at SD Gugus VIII, Kintamani District. This can be seen from the difference in students' average score in science knowledge competency, where the experimental group average score is higher than the control group. Thus, the SFE learning model has a positive influence on the science knowledge competence in fifth-grade elementary school students. Mind mapping media can make students look very interested in listening to the material presented by the teacher. When delivering material, media also provides new experiences for students and makes students easy to understand the material because the material presentation through mind mapping structured outlining the learning material. It easier for students to understand the material.

\section{References}

Agung, A. G. (2016). Statistik Dasar untuk Pendidikan. Aditya Media Pubishing.

Berlin, S., \& Kurniasih, I. (2015). Ragam Pengembangan Model Pembelajaran Untuk Peningkatan Profesionalitas Guru (A. Jay (ed.); I). Kata Pena.

Fauzi, D. R., Kusmariyatni, N. N., \& Mahadewi, L. P. P. (2016). Pengaruh Model Pembelajaran SFAE Bermediakan Mind Mapping Terhadap Hasil Belajar PKn Siswa. E-Journal PGSD Universitas Pendidikan Ganesha, 6(3), 1-11. https://doi.org/http://dx.doi.org/10.23887/jjpgsd.v4i3.8648

Hendawati, Y., Putri, S. U., Pratomo, S., \& Widianingsih, F. (2018). Penerapan Model Mind Mapping Untuk Meningkatkan Penguasaan Konsep IPA Di Sekolah Dasar. Metodik Didaktik, 13(2), 113-124. https://doi.org/https://doi.org/10.17509/md.v13i2.9498

Hendrawan, G. (2017). Pengaruh Model Pembelajaran SAVI Berbasis Mind Mapping Terhadap Motivasi Belajar IPS Di SD. Jurnal Mimbar PGSD Universitas Pendidikan Ganesha, 6(1).

Huda, M. (2013). Model-Model Pengajaran dan Pembelajaran. Pustaka Belajar.

Lestari, dkk I. (2014). Pengaruh Model Pembelajaran Student Facilitator And Explaining Terhadap Hasil Belajar IPA Kelas V. Jurnal Mimbar PGSD Universitas Pendidikan Ganesha, 2(1).

Masnun, H. M. (2016). Penerapan Pendekatan Saintifik Dalam Pembelajaran Tematik. Al Ibtida, 3(1), 93-115. https://doi.org/https://doi.org/10.24235/al.ibtida.snj.v3i1.590

Mudarini, dkk H. (2017). Pengaruh Pembelajaran Student Facilitator And Explaining (SFAE) Berbantuan Media Kartu Terhadap Hasil Belajar IPA Siswa. Jurnal Mimbar PGSD Universitas Pendidikan Ganesha, $5(2), 1-11$

Mulyadin. (2016). Implementasi Kebijakan Pembelajaran Tematik Terpadu Kurikulum 2013 Di SDN Kauman 1 Malang Dan SD Muhammadiyah 1 Malang. Jurnal Edutama, 3(2), 31-48. https://doi.org/http://dx.doi.org/10.30734/jpe.v3i2.35

Pujiastuti, I. (2017). Pengaruh Metode Diskusi Berbantuan Mind Mapping Terhadap Hasil Belajar Mahasiswa PBSI Pada Mata Kuliah Semantik. Bahastra, 37(2), 148-155. https://doi.org/http://dx.doi.org/10.26555/bahastra.v37i2.6855

Putra, P. (2017). Bangun, Penerapan Pendekatan Inkuiri Pada Mata Pelajaran IPA Untuk Mengembangkan Karakter Siswa Di SDN 01 Kota. Jurnal Madrasah Ibtidaiyah, 3(1), 28-47. https://doi.org/http://dx.doi.org/10.31602/muallimuna.v3i1.953

Ratnani, D. A. S. (2019). Peningkatan Kreativitas Siswa SMP Wisata Sanur Melalui Penerapan Model Pembelajaran Group Investigation (GI) Berbasis Media Mind Mapping. Biodik: Jurnal Ilmiah Pendidikan 
Biologi, 5(2), 150-163. https://doi.org/https://doi.org/10.22437/bio.v5i2.6416

Samatowa, Us. (2010). Pembelajaran IPA di Sekolah Dasar. PT Indeks.

Shoimin, A. (2014). 68 Model Pembelajaran Inovatif dalam Kurikulum 2013. AR-Ruzz Media.

Sophuan. (2018). Peningkatkan Keterampilan Mengajar Guru SMP Mata Pelajaran IPA Dalam Menerapkan Pendekatan Saintifik. Tadrib, 4(2), 335-355. https://doi.org/https://doi.org/10.19109/tadrib.v4i2.2860

Sujuni, A., Jamal, M. A., \& Suyidno. (2014). Meningkatkan Hasil Belajar Siswa Melalui Model Pembelajaran Kooperatif Tipe Student Facilitator And Explaining. Berkala Ilmiah Pendidikan Fisika, 2(1), 31-42. https://doi.org/http://dx.doi.org/10.20527/bipf.v2i1.813

Susanto, F., Suyitno, H., \& Arifudin, R. (2014). Komparasi Model Pembelajaran TPS Dan SFE Terhadap Kemampuan Pemahaman Konsep. Unnes Journal Of Mathematics Education, 3(1), 63-68. https://doi.org/https://doi.org/10.15294/ujme.v3i1.3438

Widyawati, S. (2016). Eksperimentasi Model Pembelajaran Student Facilitator And Explaining (SFE) Terhadap Hasil Belajar Ditinjau Dari Kecerdasan Linguistik. Al-Jabar: Jurnal Pendidikan Matematika, 7(2), 267274. https://doi.org/https://doi.org/10.24042/ajpm.v7i2.41

Wiratningsih, dkk A. (2014). Pengaruh Student Facilitator And Explaining Berbantuan Peta Konsep Terhadap Hasil Belajar PKn Kelas V SD Gugus I gusti Ngurah Rai. Jurnal Mimbar PGSD Universitas Pendidikan Ganesha, 2(1). 